Masclaux, F.G. ; Hotz, P. ; Gashi, D. ; Savova-Bianchi, D. ; Oppliger, A. Assessment of airborne virus contamination in wastewater treatment plants. Environmental Research, 133:260-265, 2014.

\begin{tabular}{|l|l|}
\hline Postprint version & Final draft post-refereeing \\
\hline Journal website & $\underline{\text { http://www.sciencedirect.com/science/journal/00139351 }}$ \\
\hline Pubmed link & $\underline{\text { http://www.ncbi.nlm.nih.gov/pubmed/24981824 }}$ \\
\hline DOI & $\underline{10.1016 / \text { j.envres.2014.06.002 }}$ \\
\hline
\end{tabular}


4

27 Number of Figures: 1 28 29 30

*Corresponding author

Tel.: 0041213147416

Fax: 0041213147420

Abstract: 235 words

Text: 3134 words

\section{Assessment of airborne virus contamination in wastewater treatment plants}

${ }^{1}$ Institute for Work and Health (IST), University of Lausanne and University of Geneva, Route

Oppliger $^{*}$ de la Corniche 2, 1066 Epalinges-Lausanne, Switzerland.

${ }^{2}$ Occupational and Environmental Medicine Unit, Med. Poliklinik USZ, Rämistrasse 100,

" Present address: Department of Ecology and Evolution, University of Lausanne, Switzerland 8091 Zürich, Switzerland.

E-mail: Anne.Oppliger@hospvd.ch

E-mail address of senior researchers: Frederic.Mascalux@unil.ch; Philipp.Hotz@usz.ch; 
33

34

35

\section{ABSTRACT}

Introduction: Occupational exposure to bioaerosols in wastewater treatment plants (WWTP) and its consequence on workers' health are well documented. Most studies were devoted to enumerating and identifying cultivable bacteria and fungi, as well as measuring concentrations of airborne endotoxins, as these are the main health-related factors found in WWTP. Surprisingly, very few studies have investigated the presence and concentrations of airborne virus in WWTP. However, many enteric viruses are present in wastewater and, due to their small size, they should become aerosolized. Two in particular, the norovirus and the adenovirus, are extremely widespread and are the major causes of infectious gastrointestinal diseases reported around the world. The third one, hepatitis E virus, has an emerging status. Goal and methods: This study's objectives were to detect and quantify the presence and concentrations of 3 different viruses (adenovirus, norovirus and the hepatitis E virus) in air samples from 31 WWTP by using quantitative polymerase chain reaction (qPCR) during two different seasons and two consecutive years. Results: Adenovirus was present in $100 \%$ of summer WWTP samples and 97\% of winter samples. The highest airborne concentration measured was $2.27 \times 10^{6}$ genome equivalent $/ \mathrm{m}^{3}$ and, on average, these were higher in summer than in winter. Norovirus was detected in only 3 of the 123 air samples, and the hepatitis E virus was not detected. Conclusions: Concentrations of potentially pathogenic viral particles in WWTP air is non-negligible and could partly explain the work-related gastrointestinal symptoms often reported in employees in this sector.

Keywords: adenovirus; bioaerosol; norovirus; occupational health; sewage; hepatitis E virus 


\section{Funding}

60 This work was supported by grant EST-09-69 from ANSES (French Agency for Food,

61 Environmental and Occupational Health \& Safety), and a grant from the Swiss National 62 Accident Insurance Fund (SUVA).

63 


\section{Introduction}

Wastewater is a significant transmission route for several viral and bacterial pathogens which are reflected in both the clinical and subclinical infections currently present in the human population (Vaidya et al., 2002). Therefore, wastewater treatment workers are exposed to a lot of biological risks and have been shown to be at a higher risk of developing a large variety of work-related symptoms compared with the general population, including respiratory and gastrointestinal (e.g. diarrhoea) effects (Douwes et al., 2001; Rylander, 1999; Thorn et al., 2002; Thorn and Beijer, 2004). Viruses could be responsible from some of these work-related symptoms observed in WWTP workers. Numerous studies have investigated the presence of airborne cultivable bacteria in WWTP (Oppliger et al., 2005; Rinsoz et al., 2009; HeinonenTanski et al. , 2009; Haas et al., 2010; Kaarakainen et al., 2011; Han et al., 2013). However, very few studies have investigated the airborne concentrations of virus particles in WWTP although the health risk for workers is present (Divizia et al., 2008).

Among the most common human viral infections found in temperate regions and transmitted by the faecal-oral route, norovirus (NoV) and human adenovirus (AdV) are good candidates for being responsible for the observed symptoms reported in WWTP workers. $\mathrm{NoV}$ is recognized as the major source of gastroenteritis outbreaks in adults worldwide. It is presumed that infection mainly occurs by person-to-person transmission and consumption of contaminated food or water, but airborne transmission is likely to occur too (Friesema et al., 2009; Kimura et al., 2011; Kirking et al., 2010; Wikswo et al., 2011; Uhrbrand et al., 2012). $\mathrm{AdV}$ is made up of seven groups $(\mathrm{A}-\mathrm{G})$, with a total of 57 serotypes associated with a number of clinical syndromes such as gastroenteritis, respiratory diseases and conjunctivitis. They spread primarily via respiratory droplets, however, they can also spread along faecal routes and their presence in wastewater (Carducci et al., 2008; Jiang, 2006) and air has been demonstrated (Echavaria et al., 2000; Carducci et al., 2011; Wan et al., 2012). Another virus 
which deserves particular attention, because of its emerging status, is the hepatitis E virus (HEV) (Dalton et al., 2008). It is responsible for enterically transmitted viral hepatitis around the world. In industrialized countries, the endemic genotype $3 \mathrm{HEV}$ appears to be more common than previously thought, even if it is rarely virulent. One main route of human transmission of the genotype 3 has been suggested to be via consumption of contaminated pork, but waterborne transmission cannot be excluded in these countries (Renou et al. 2008). HEV has been detected in wastewater in France (Clemente-Casares et al., 2003), Italy (La Rosa et al., 2010), Spain (Clemente-Casares et al., 2009; Rodriguez-Manzano et al., 2010) and, very recently, the presence of HEV (genotype 3) was reported in 50\% of water samples from 31 WWTPs in Switzerland (Masclaux et al., 2013).

Treatment of wastewater generates aerosols of different sizes and all microorganisms present in wastewater can consequently be aerosolized and deposited on surfaces (Han et al 2013). Thus, WWTP workers can be exposed to viral particles either via aerosol inhalation/deglutition or via contact with contaminated surfaces, clothes or tools. Both regular monitoring and accurate estimations of exposure to airborne viral particles are therefore important in the assessment of occupational exposure risks and their prevention. Using quantitative polymerase chain reaction (qPCR), this study aimed to investigate the presence of 3 different viruses (AdV groups $\mathrm{F}$ and $\mathrm{E} / \mathrm{D}, \mathrm{NoV}$ and $\mathrm{HEV}$ ) in air samples from 31 WWTPs located in the same area as a previous cohort study (Jeggli et al., 2004; Tschopp et al., 2009) during two different seasons.

\section{Materials and methods}

\subsection{Description of study sites}

Thirty-one out of the 79 WWTP in the Canton of Zurich, Switzerland (about 1.39 million inhabitants; $1,729 \mathrm{~km}^{2}$ ), were selected for study in order to represent a broad array of plant 
115 sizes $(2-117$ workers). These included 6 very large $(>50,000$ inhabitants or inhabitant-

116 equivalents), 12 large (10,000-50,000 inhabitants or inhabitant-equivalents) and 13 small

117 WWTPs (2,000-10,000 inhabitants or inhabitant-equivalents). The selection was made using

118 the following criteria. First, WWTPs where a seroconversion in workers had been positively

119 ascertained in a recent cohort study on hepatitis E incidence (Tschopp et al., 2009) were

120 included. Second, the WWTP servicing Zurich's international airport was included because

121 international travel increases the probability of the occurrence of HEV. Third, WWTP where

122 occupational hygiene measurements had been taken in a previous study (Oppliger et al., 2005;

123 Daneshzadeh Tabrizi et al., 2010) were also included. Finally, further WWTPs were selected

124 to represent a well-balanced sample of sizes across the whole canton. All the plants were 125 municipal plants treating household wastewater only, and comprised a cleaning and an 126 activated sludge step (Zurich WWTP website, 2013). The presence of the 3 viruses under investigation (NoV, AdV and $\mathrm{HEV}$ ) in raw wastewater was known from a previous study

128 (Masclaux et al., 2013).

129

130

\subsection{Air sampling}

131 Each WWTP was visited once in winter (mean temperature $4^{\circ} \mathrm{C}$ ) and once in summer (mean 132 temperature $21^{\circ} \mathrm{C}$ ). At each visit, samples were collected at stationary points, continuously

133 for at least 1 hour during the working day in two different workstations: (i) one sample in the

134 enclosed area, at the water inlet, near the rake that removes big particles from incoming water 135 (termed 'inside'), and (ii) one sample in the unenclosed area, above the bubbling aeration 136 basin (termed 'outside'). All samples were collected $1.5 \mathrm{~m}$ above the floor or the basins. In 137 each WWTP, the inside and outside samples were taken in parallel during the same day.

138 In total, 123 airborne virus samples were collected onto $3 \mu \mathrm{m}$ pore size, $25 \mathrm{~mm}$ gelatine filters 139 embedded in standard cassettes (SKC, Inc. Eighty Four, USA). Sampling was carried out 140 using a pocket pump (MSA Escort Elf, Mine Safety Appliance Company, Pittsburgh, PA, 
141 USA, or SKC pocket pump 210-1002, SKC Inc., PA, USA) calibrated at $4 \mathrm{~L} \mathrm{~min}^{-1}$. Airflow

142 was calibrated using a pocket calibrator (DryCal DCLite, Bios International, Pompton Plains,

143 NJ, USA), both before and after field sampling.

144 After sampling, filters were immediately immersed in $1 \mathrm{~mL}$ of RNAlater (Ambion, Life

145 Technologies, Europe) stabilizing solution. Samples were kept at $4{ }^{\circ} \mathrm{C}$ until return to the

146 laboratory, where they were stored at $-20^{\circ} \mathrm{C}$.

147 Given that the 3 investigated viruses are potentially pathogenic, we do not expect to find them

148 in non contaminated ambient air. That is why we did not collect control air samples in other

149 environment.

\subsection{Virus recovery and nucleic acid extraction}

152 Samples were allowed to liquefy briefly at room temperature and were then kept on ice. An amount of $2 \times 10^{6}$ genome equivalent (GE) copies of the control virus (RYMV, rice yellow mottle virus) was added to each sample. After brief swirling, and 10 min incubation, samples were centrifuged at $1,500 \mathrm{~g}$ in a swinging rotor for $5 \mathrm{~min}\left(4^{\circ} \mathrm{C}\right)$. The supernatant was carefully recovered in a $2 \mathrm{~mL}$ centrifuge tube, and centrifuged for $10 \mathrm{~min}$ at $16,000 \mathrm{~g}$ to pellet

157 precipitated materials. The pellet was treated with $560 \mu \mathrm{L}$ of AVL (viral lysis buffer) from the 158 QIAamp Viral RNA Mini Kit (Qiagen AG, Hombrechtikon Switzerland) as per the 159 manufacturer's protocol. The gelatine filter was treated immediately with $560 \mu \mathrm{L}$ of AVL 160 buffer. During 10 min incubation, both preparations were combined in the same tube and a 161 volume of $120 \mu \mathrm{L}$ of ethanol was added to the sample. After the incubation period, the 162 samples were extracted as per the manufacturer's protocol. After final elution, an additive 163 ethanol precipitation step was carried out on the samples, using Glycoblue (Ambion, Life 164 Technologies, Europe) as a co-precipitant. Lastly, the nucleic acids were suspended in a final 165 volume of $60 \mu 1$ of AVE buffer and stored at $-20^{\circ} \mathrm{C}$ until use. 


\subsection{Reverse transcription}

RNA viruses (NoV and VHE) were reverse-transcribed using the SuperScript III First-Strand

$171 \mu \mathrm{L}$ reaction mixture was prepared as per the manufacturer's protocol, including RNasin

172 (Promega AG, Wisconsin, USA). The reaction was incubated for $60 \mathrm{~min}$ at $50^{\circ} \mathrm{C}$, followed by

173 heat-inactivation at $70^{\circ} \mathrm{C}$ for $15 \mathrm{~min}$. The volume was finally adjusted to $100 \mu \mathrm{L}$ with $\mathrm{TE}$ 174 (Tris EDTA buffer) $0.1 \mathrm{X}$.

\section{5. $q P C R$ assay}

177 The qPCR reaction was performed on $5 \mu \mathrm{L}$ of nucleic acid solution (either DNA or cDNA) using the qPCR Core kit (No ROX, with dUTP) from Eurogentec (www.eurogentec.com). Three duplex qPCR assays were developed to allow simultaneous detection of viruses: NoVGGII/RYMV and HEV/RYMV for RNA viruses, and AdV-40/AdV-E/D for DNA viruses.

181 The reaction efficiencies (Table 2) were measured on serial 10-fold dilution mixtures of 2

182 virus amplicons cloned in pGEM-T as described for the monoplex assays. Cross-reactivity between the assays in duplex was evaluated by comparing the amplification of the target in single-plasmid solution and in multiple plasmid solution. The primers used are detailed in Table 1. RYMV was used as a control for the quality of each sample. The sample validation

186 threshold was $4 \times 10^{5}$ GE copies of RYMV. Samples with an amplification of spiked RYMV 187 under the threshold were reanalyzed or not considered, as described in Masclaux et al. (2013).

188 The reactions were run in triplicate on a RotorGene-3000 (Qiagen AG, Hombrechtikon 189 Switzerland) using the following profile: digestion with uracil-N-glycosylase at $50^{\circ} \mathrm{C}$ for 2 $190 \mathrm{~min}$, initial denaturation at $95^{\circ} \mathrm{C}$ for $10 \mathrm{~min}, 45$ cycles of $15 \mathrm{~s}$ denaturation at $95^{\circ} \mathrm{C}$, and $30 \mathrm{~s}$ 
191

192

193

194

195

196

197

198

199

200

201

202

203

204

205

206

207

208

209

210

211

212

213

214

215

216

annealing at $60^{\circ} \mathrm{C}$. No template controls were included in the runs. Good laboratory practices were followed strictly to prevent PCR contamination (separated working areas and different material for each extraction, preparation and amplification of samples). Quantitative data were obtained using RotorGene software, version 6.1.93, and were subsequently analyzed with custom-designed Excel spreadsheets using the standard curve equation as a reference for the quantification. All signals (Cq values) above the limit of detection (LOD) were considered as positive for the detection (Table 2). A standard curve was generated for each virus using tenfold dilutions of plasmid DNA containing the corresponding PCR product (see details in Masclaux et al., 2013). Concentrations were expressed in genome equivalent (GE) copies $/ \mu 1$ and converted to GE copies $/ \mathrm{m}^{3}$ of air on the basis of the volume of air sampled.

\section{Results}

Airborne AdV-F was detected in all the WWTP (either inside or outside or both) in summer and $97 \%$ of WWTPs $(30 / 31)$ in winter. In total, $84 \%(104 / 123)$ of samples were positive (Table 3). Among these positive samples, 61.5\% (64/104) were above the limit of quantification (LOQ) (i.e. $2.72 \times 10^{3} \mathrm{GE}$ copies $/ \mathrm{m}^{3}$ ) with a maximum concentration of $2.27 \times$ $10^{6} \mathrm{GE}$ copies $/ \mathrm{m}^{3}$. In summer, $93 \%(58 / 62)$ of samples were positive compared to $75 \%$ $(46 / 61)$ in winter. This difference was statistically significant (Pearson Chi-square $=7.74$, df $=1, p=0.005)$. In summer, $75 \%(44 / 58)$ of positive samples were above the LOQ compared to only $20 \%(20 / 46)$ in winter (Pearson Chi-square $=11.36, \mathrm{df}=1, \mathrm{p}=0.001)$, and the mean concentration of airborne AdV of positive samples (samples above the LOQ) was higher in summer than in winter (mean $\pm \mathrm{SE}$, median: $95,179 \pm 54,066 \mathrm{GE}$ copies $/ \mathrm{m}^{3}, 12,492 \mathrm{GE}$ copies $/ m^{3}, \mathrm{~N}=44$; versus $31,121 \pm 10,594 \mathrm{GE}$ copies $/ \mathrm{m}^{3}, 13,884 \mathrm{GE}$ copies $/ \mathrm{m}^{3}, \mathrm{~N}=20$ respectively; Mann-Whitney $\mathrm{U}$ test $=2,652, \mathrm{p}<0.001, \mathrm{~N}=64)$ (Fig 1, and Table 4). There were no differences in AdV occurrence between each WWTP's two sampling sites, with 
$21785.4 \%(53 / 62)$ of positive outside samples compared to 83.6\% (51/61) of positive inside 218 samples (Pearson Chi-square $=0.08, \mathrm{df}=1, \mathrm{p}=0.7)$. Median concentrations were slightly 219 lower outside than inside (Fig 1), but these differences were not significant (Mann-Whitney U 220 test, $\mathrm{U}=2001.5, \mathrm{p}=0.569$ ). The size of the WWTPs (small, large or very large) had no 221 significant influence on airborne concentrations of AdV (Kruskal-Wallis $=2.474, \mathrm{p}=0.29, \mathrm{~N}$ $222=31)$. Group E/D adenoviruses were only detected in winter in 6 air samples $(2$ inside and 4 223 outside).

NoV was detected in 3 of the 123 air samples, and these results were below the LOQ (i.e. $<6.55 \times 10^{2} \mathrm{GE}$ copies $\left./ \mathrm{m}^{3}\right)$. HEV was not detected in any of the 123 air samples (LOQ = $3.34 \times 10^{3} \mathrm{GE}$ copies $\left./ \mathrm{m}^{3}\right)$.

\section{Discussion}

Of the 3 different pathogenic virus species previously found in influent water at WWTP in the

Canton of Zurich, only AdV was very frequently present (84\% of 124 samples) in relatively high concentrations (up to $22.76 \times 10^{5}$ viral particles $/ \mathrm{m}^{3}$ ) in WWTP air samples. The HEV was not observed at all, and the NoV was detected in only $2.4 \%$ of samples. These results therefore demonstrated that the working environments of WWTP can expose workers to airborne pathogenic viruses. The AdV are known to be more resistant to the effects of UV light than other enteric viruses (Thurston-Enriquez et al., 2003). Moreover, a lot of non237 enveloped viruses tend to be more stable in environments with relatively high relative 238 humidity (Yang and Marr, 2012), as is the case in WWTP and they could therefore remain 239 infectious in aerosol for a long time. Once in suspension in the air, AdV can be deposited onto 240 any WWTP surface, and contamination of workers can occur not only via inhalation but also 241 via contaminated hands, objects or surfaces. When AdV are inhaled, respiratory symptoms 242 (fever, pharyngitis, tonsillitis, cough, and sore throat) can occur. When ingested, some 
243

244 diarrhea and gastroenteritis.

Numerous studies have reported that WWTP workers have more frequent

246 gastrointestinal symptoms than the general population, though without highlighting clear

247 relationships with occupational exposure to one specific biological agent (Thorn and Kerekes,

248 2001; Khuder et al., 1998; Thorn et al., 2002; Douwes et al., 2001). Rylander (1999) reported

249 prevalence of diarrhea of nearly $45 \%$ in Swedish sewage workers (versus 3\% in the control

250 population), and assumed that endotoxins are responsible of these symptoms. Exposure to

251 airborne endotoxins was also suspected to be related to the diarrheal symptoms observed in

252 workers from the WWTP investigated in this study (Jeggli et al., 2004), but the authors

253 noticed that other components could also be involved. Therefore, the presence of high

254 airborne quantities of $\mathrm{AdV}$ in almost all WWTP, sometimes in association with airborne NoV,

255 could explain the gastrointestinal symptoms often reported in WWTP, yet never elucidated.

256 To the best of our knowledge, this was the first time that the presence of airborne AdV was

257 investigated in WWTP, and such high airborne concentrations were previously reported only

258 in solid-waste processing facilities in Italy, where AdV was found in $25 \%(8 / 40)$ of air

259 samples, with concentrations ranging between $10 \times 10^{5}$ to $98 \times 10^{6}$ viral particles $/ \mathrm{m}^{3}$

260 (Carducci et al., 2013). As point of comparison, in Taiwan, a survey in a paediatric

261 emergency room showed that airborne concentrations of AdV were only between $<10$ and

262104 copies $/ \mathrm{m}^{3}$ (Wan et al., 2012). The major limit of our study is that the infectivity of these

263 viral particles is unknown, since PCR methods of quantification take into account both

264 infectious and non-infectious viral particles. However, AdV is known to be very resistant

265 (Gordon et al., 1993; Thurston-Enriquez et al., 2003; Enriquez et al., 1995), and it is likely to

266 remain infectious in the environment for a long time. In a recent study (Carducci et al., 2013)

267 in solid-waste processing facilities in Italy, $75 \%$ of the surface samples which were positive 
268 for AdV using PCR were confirmed as infectious using cell culture. The infectious dose of $269 \mathrm{AdV}$ is estimated at $30-1,000$ viral particles, thus, with regard to the high airborne virus 270 concentrations found in this study, potential infection via aerosols cannot be excluded., even 271 if it was not found in the cross-sectional examination of these workers (Steiner et al., 2005). Due to the specificity of the primers used, it can be surmised that airborne AdV 273 isolated in this study belong to group $\mathrm{F}$ (type 40-41), i.e. one of those involved in 274 gastrointestinal tropism. The presence of $\mathrm{AdVs}$ from the groups $\mathrm{E} / \mathrm{D}$, which can be more 275 specifically involved in respiratory tropism, was also identified in 6 samples. The present study also observed that concentrations of $\mathrm{AdV}$ viruses were higher in summer than in winter. This is also the case for other microbial aerosols in WWTP (Grisoli et al. 2009; Oppliger et al. 2005) and certainly due to the higher temperature measured in summer time,

NoV was only detected in 3 air samples and at concentrations too low to be quantifiable. The presence of airborne NoV in WWTP was also detected at a concentration of 1,420 viral particle copies $/ \mathrm{m}^{3}$ in an air sample in Denmark (Uhrbrand et al., 2011). These two results show that the risk of airborne NoV exposure does indeed exist for wastewater workers. Even though the levels and frequencies of exposure are lower than those to AdV, because the 284 infectious dose of $\mathrm{NoV}$ is at an extremely low level (18 viral particles) (Teunis et al., 2008), and because NoV is known to survive very well in adverse environments (Rodriguez-Lazaro et al., 2012), the risk of contracting an infection is non-negligible, and the risk is even greater for immunocompromised patients since more severe symptoms can occur.

HEV was not detected in air samples despite its presence in $50 \%$ of wastewater 289 samples. This can be explained by the fact that HEV was found in very low concentrations 290 (detectable, but not quantifiable) in wastewater compared to the waterborne concentrations of $291 \mathrm{AdV}$ and NoV, and therefore aerosolisation was less probable. This can also be explained by 292 the fact that we have collected small volume of air which limits the probability of detecting 
293 low airborne virus concentrations. Due to the high concentrations of AdV and NoV 294 previously found in the effluent of the WWTP investigated (Masclaux et al., 2013), it is 295 highly likely that influent water is the source of airborne contamination in WWTP. 296 Investigated WWTP are geographically isolated from urban centres and no other potential 297 sources of AdV or NoV were present in the near environment of the WWTP. However, the

298 lack of control air samples collected in other outdoor environments is a limit of our study. 299 Once aerosolised, certain viruses can be disseminated over long distances and several 300 examples of airborne virus transmission exist. For instance, the foot and mouth animal virus, 301 SRAS and the influenza virus have all been reported to travel over very long distances 302 (Gloster et al., 2010; Booth et al., 2005; Ssematimba et al., 2012). The dissemination of viral 303 particles from WWTP into the environment disserves to be further evaluated to assess 304 possible public health risks.

\section{Conclusion}

307 Pathogenic viral particles responsible of gastrointestinal symptoms are frequently present in 308 WWTP air. Occupational exposure to these airborne micro-organisms could explain part of 309 the work-related gastrointestinal symptoms often reported in this occupational sector, 310 especially during the first months of employment in WWTP. We can infer that workers' 311 repeated exposure to these viruses triggers off a good immune response and consequently a 312 decrease in symptoms after the first year of work. However, because more and more workers 313 (included workers of WWTP) use immunosuppressive drugs (transplant patients, HIV 314 patients, etc.), some can develop severe complications when infected by these viruses. 315 Objective data useful for an adequate risk assessment for these workers are largely lacking, 316 and this subject requires further investigation. 


\section{Acknowledgements}

We gratefully thank Dr Jean-Paul Brizard for his gift of RYMV stock. We very much thank the workers and the director of the Canton of Zurich's sewage plants, and Stéphanie Héritier and Denis Thonney from the WWTP Lausanne for their constant support. Thanks to Darren Hart (admin@publish-or-perish.ch) for English editing.

\section{References}

Booth, T. F., Kournikakis, B., Bastien, N., Ho, J., Kobasa, D., Stadnyk, L., Li, Y., Spence, M., Paton, S., Henry, B., Mederski, B., White, D., Low, D. E., McGeer, A., Simor, A., Vearncombe, M., Downey, J., Jamieson, F. B., Tang, P., Plummer, F., 2005. Detection of airborne severe acute respiratory syndrome (SARS) coronavirus and environmental contamination in SARS outbreak units. J. Infect. Dis. 191, 1472-1477.

Carducci, A., Federigi, I., Verani, M., 2013. Virus occupational exposure in solid waste processing facilities. Ann. Occup. Hyg. 57,1115-1127.

Carducci, A., Morici, P., Pizzi, F., Battistini, R., Rovini, E., Verani, M., 2008. Study of the viral removal efficiency in a urban wastewater treatment plant. Water Sc. Technol. 58, 893-897.

Carducci, A., Verani, M., Lombardi, R., Casini, B., Privitera, G., 2011. Environmental survey to assess viral contamination of air and surfaces in hospital settings. J. Hosp. Infect. $77,242-247$.

Clemente-Casares, P., Pina, S., Buti, M., Jardi, R., MartIn, M., Bofill-Mas, S., Girones, R., 2003. Hepatitis E virus epidemiology in industrialized countries. Emerg. Infect. Dis. 9, 448-454.

Clemente-Casares, P., Rodriguez-Manzano, J., Girones, R., 2009. Hepatitis E virus genotype 3 and sporadically also genotype 1 circulate in the population of Catalonia, Spain. J. Water Health. 7, 664-673.

Dalton, H.R., Bendall, R., Ijaz, S., Banks, M., 2008. Hepatitis E: an emerging infection in developed countries. Lancet Infect. Dis. 8, 698-709.

Divizia, M., Cencioni, B., Palombi, L., Pana, A., 2008. Sewage workers: risk of acquiring enteric virus infections including Hepatitis A. New Microbiol. 31, 337-341.

Douwes, J., Mannetje, A., Heederik, D., 2001. Work-related symptoms in sewage treatment workers. Ann. Agric. Environ. Med. 8, 39-45.

Echavarria, M., Kolavic, S. A., Cersovsky, S., Mitchell, F., Sanchez, J. L., Polyak, C., Innis, B. L., Binn, L. N., 2000. Detection of adenoviruses (AdV) in culture-negative environmental samples by PCR during an AdV-associated respiratory disease outbreak. J. Clin. Microbiol. 38, 2982-2984.

Enriquez, C. E., Hurst, C. J., Gerba, C. P., 1995. Survival of the enteric adenovirus-40 and adenovirus-41 in tap, sea, and waste-water. Water Res. 29, 2548-2553. 
Friesema, I. H. M., Vennema, H., Heijne, J. C. M., de Jager, C. M., Morroy, G., van den Kerkhof, J. H. T. C., de Coster, E. J. M., Wolters, B. A., ter Waarbeek, H. L. G., Fanoy, E. B., Teunis, P. F. M., van der Linde, R., van Duynhoven, Y. T. H. P., 2009. Norovirus outbreaks in nursing homes: the evaluation of infection control measures. Epidemiol. Infect. 137, 1722-1733.

Gloster, J., Jones, A., Redington, A., Burgin, L., Sorensen, J. H., Turner, R., Dillon, M., Hullinger, P., Simpson, M., Astrup, P., Garner, G., Stewart, P., D'Amours, R., Sellers, R., Paton, D., 2010. Airborne spread of foot-and-mouth disease - Model intercomparison. Vet. J. 183, 278-286.

Gordon, Y. J., Gordon, R. Y., Romanowski, E., Araullocruz, T. P., 1993. Prolonged recovery of desiccated adenoviral serotypes 5, 8, and 19 from plastic and metal-surfaces invitro. Ophthalmol. 100, 1835-1840.

Grisoli, P., Rodolfi, M., Villani, S., Grignani, E., Cottica, D., Berri, A., Picco, A. M., Dacarro, C., 2009. Assessment of airborne microorganism contamination in an industrial area characterized by an open composting facility and a wastewater treatment plant. Environ. Res. 109, 135-142.

Haagsma, J. A., Tariq, L., Heederik, D. J., Havelaar, A. H., 2012. Infectious disease risks associated with occupational exposure: a systematic review of the literature. Occup. Environ. Med. 69, 140-146.

Haas, D., Unteregger, M., Habib, J., Galler, H., Marth, E., Reinthaler, F. F., 2010. Exposure to Bioaerosol from Sewage Systems. Water Air Soil Poll. 207, 49-56.

Han, Y. P., Li, L., Liu, J. X., 2013. Characterization of the airborne bacteria community at different distances from the rotating brushes in a wastewater treatment plant by $16 \mathrm{~S}$ rRNA gene clone libraries. J. Environ. Sci. China. 25, 5-15.

Heinonen-Tanski, H., Reponen, T., Koivunen, J., 2009. Airborne enteric coliphages and bacteria in sewage treatment plants. Water Res. 43, 2558-2566.

Huang, M. L., Nguy, L., Ferrenberg, J., Boeckh, M., Cent, A., Corey, L., 2008. Development of multiplexed real-time quantitative polymerase chain reaction assay for detecting human adenoviruses. Diag. Microbiol. Infect. Dis. 62, 263-271.

Jeggli, S., Steiner, D., Joller, H., Tschopp, A., Steffen, R., Hotz, P., 2004. Hepatitis E, Helicobacter pylori, and gastrointestinal symptoms in workers exposed to waste water. Occup. Environ. Med. 61, 622-627.

Jiang, S. C. , 2006. Human adenovirus in water: occurrence and health implications: a critical review. Environ. Sci. Technol. 40, 7132-7140.

Jothikumar, N., Lowther, J. A., Henshilwood, K., Lees, D. N., Hill, V. R., Vinje, J., 2005a. Rapid and sensitive detection of norovirus by using TaqMan-based one-step reverse transcription-PCR assays and application to naturally contaminated shellfish samples. Appl. Environ. Microbiol. 71, 1870-1875.

Jothikumar, N., Cromeans, T. L., Hill, V. R., Lu, X. Y., Sobsey, M. D., Erdman, D. D., 2005b. Quantitative real-time PCR assays for detection of human adenoviruses and identification of serotypes 40 and 41. Appl. Environ. Microbiol. 71, 3131-3136.

Jothikumar, N., Cromeans, T. L., Robertson, B. H., Meng, X. J., Hill, V. R.,

2006. A broadly reactive one-step real-time RT-PCR assay for rapid and sensitive detection of hepatitis E virus. J. Virol. Meth. 131, 65-71.

Kaarakainen, P. , Rintala, H., Meklin, T. Karkkainen, P., Hyvarinen, A., Nevalainen, A., 2011. Concentrations and Diversity of Microbes from Four Local Bioaerosol Emission Sources in Finland. J. Air Waste Manag. Ass. 61, 1382-1392.

Khuder, S. A., Arthur, T., Bisesi, M. S., Schaub, E. A., 1998. Prevalence of infectious diseases and associated symptoms in wastewater treatment workers. Am. J. Ind. Med. 33, 571-577. 
Kimura, H., Nagano, K., Kimura, N., Shimizu, M., Ueno, Y., Morikane, K., Okabe, N., 2011. A norovirus outbreak associated with environmental contamination at a hotel. Epidemiol. Infect. 139, 317-325.

Kirking, H. L., Cortes, J., Burrer, S., Hall, A. J., Cohen, N. J., Lipman, H., Kim, C., Daly, E. R., Fishbein, D. B., 2010. Likely Transmission of Norovirus on an Airplane, October 2008. Clin. Infect. Dis. 50, 1216-1221.

Kouassi, N.K., N'Guessan, P., Albar, L., Fauquet, C.M., Brugidou, C., 2005. Distribution and Characterization of Rice yellow mottle virus: A Threat to African Farmers. Plant. Dis. 89, 124-133.

La Rosa, G., Pourshaban, M., Iaconelli, M., Spuri Vennarucci, V., Muscillo, M.,2010. Molecular Detection of Hepatitis E Virus in Sewage Samples. Appl. Environ. Microbiol. 76, 5870-5873.

Masclaux, F. G., Hotz, P., Friedli, D., Savova-Bianchi, D., Oppliger, A., 2013. High occurrence of hepatitis $\mathrm{E}$ virus in samples from wastewater treatment plants in Switzerland and comparison with other enteric viruses. Water Res. 47, 5101-5109.

Oppliger, A., Hilfiker, S., Duc, T. V., 2005. Influence of seasons and sampling strategy on assessment of bioaerosols in sewage treatment plants in Switzerland. Ann. Occup. Hyg. 49, 393-400.

Renou, C., Moreau, X., Pariente, A., Cadranel, J. F., Maringe, E., Morin, T. Causse, X . Payen, J. L., Izopet, J., Nicand, E., Bourliere, M., Penaranda, G., Hardwigsen, J., Gerolami, R., Peron, J. M., Pavio, N., 2008. A national survey of acute hepatitis E in France. Alim. Pharmacol. Therapeutics. 11, 1086-1093.

Rinsoz, T., Hilfiker, S., Oppliger, A., 2009. Quantification of Thermotolerant Campylobacter in Swiss Water Treatment Plants, by Real-Time Quantitative Polymerase Chain Reaction. Water Environ. Res. 81, 929-933.

Rodriguez-Lazaro, D., Cook, N., Ruggeri, F. M., Sellwood, J., Nasser, A., Nascimento, M. S. J., D'Agostino, M., Santos, R., Carlos Saiz, J., Rzezutka, A., Bosch, A., Girones, R., Carducci, A., Muscillo, M., Kovac, K., Diez-Valcarce, M., Vantarakis, A., von Bonsdorff, C.-H., Husman, A. M. d. R., Hernandez, M., van der Poel, W. H. M., 2012. Virus hazards from food, water and other contaminated environments. Fems Microbiol. Rev. 36, 786-814.

Rodriguez-Manzano, J., Alonso, J. L., Ferrus, M. A., Moreno, Y., Amoros, I., Calgua, B., Hundesa, A., Guerrero-Latorre, L., Carratala, A., Rusinol, M., Girones, R., 2012. Standard and new faecal indicators and pathogens in sewage treatment plants, microbiological parameters for improving the control of reclaimed water. Water Sc. Technol. 66, 2517-2523.

Rylander, R., 1999. Health effects among workers in sewage treatment plants. Occup. Environ. Med. 56, 354-357.

Ssematimba, A., Hagenaars, T. J., de Jong, M. C. M., 2012. Modelling the wind-borne spread of highly pathogenic avian influenza virus between farms. Plos One. 7, e31114.

Steiner, D., Jeggli, S., Tschopp, A., Bernard, A., Oppliger, A., Hilfiker, S., Hotz, P., 2005. Clara cell protein and surfactant protein B in garbage collectors and in wastewater workers exposed to bioaerosols. Int. Arch. Occup. Environ. Health. 78, 189-197.

Teunis, P. F. M., Moe, C. L., Liu, P., Miller, S. E., Lindesmith, L., Baric, R. S., Le Pendu, J., Calderon, R. L., 2008. Norwalk virus: How infectious is it? J. Med. Virol. 80, 14681476.

Thorn, J., Beijer, L., 2004. Work-related symptoms and inflammation among sewage plant operatives. Int. J. Occup. Environ. Health. 10, 84-89.

Thorn, J., Beijer, L., Rylander, R., 2002. Work related symptoms among sewage workers: a nationwide survey in Sweden. Occup. Environ. Med. 59, 562-566. 
Thorn, J., Kerekes, E., 2001. Health effects among employees in sewage treatment plants: A literature survey. Am. J. Ind. Med. 40, 170-179.

Thurston-Enriquez, J. A., Haas, C. N., Jacangelo, J., Riley, K., Gerba, C. P., 2003. Inactivation of feline calicivirus and adenovirus type 40 by UV radiation. App. Environ. Microbiol. 69, 577-582.

Tschopp, A., Joller, H., Jeggli, S., Widmeier, S., Steffen, R., Hilfiker, S., Hotz, P., 2009. Hepatitis E, Helicobacter pylori and peptic ulcers in workers exposed to sewage: a prospective cohort study. Occup. Environ. Med. 66, 45-50.

Uhrbrand, K., Schultz, A. C., Madsen, A. M., 2011. Exposure to Airborne Noroviruses and Other Bioaerosol Components at a Wastewater Treatment Plant in Denmark. Food Environ. Virol. 3, 130-137.

Vaidya, S. R., Chitambar, S. D., Arankalle, V. A., 2002. Polymerase chain reaction-based prevalence of hepatitis A, hepatitis E and TT viruses un sewage from an endemic area. J. Hepatol. 31, 131-136.

Wan, G.-H., Huang, C.-G., Huang, Y.-C., Huang, J.-P., Yang, S.-L., Lin, T.-Y., Tsao, K.-C., 2012. Surveillance of Airborne Adenovirus and Mycoplasma pneumoniae in a Hospital Pediatric Department. Plos One. 7.

Wikswo, M. E., Cortes, J., Hall, A. J., Vaughan, G., Howard, C., ; Gregoricus, N., Cramer, E. H., 2011. Disease transmission and passenger behaviours during a high morbidity norovirus outbreak on a cruise ship, January 2009. Clin. Infec. Dis. 52,116-1122.

Yang, W., Marr, L. C., 2012. Mechanisms by Which Ambient Humidity May Affect Viruses in Aerosols. App. Environ. Microbiol. 78, 6781-6788.

Zurich WWTP website available from URL http://www.awel.zh.ch/internet/baudirektion/awel/de/betriebe_anlagen_baustellen/abw asserreinigungsanlagen.htm 